\title{
Effect of Nutritional Supplementation on Oxidative Stress and Hormonal and Lipid Profiles in PCOS-Affected Females
}

\author{
Pallavi Dubey ${ }^{1, *}$, Sireesha Reddy ${ }^{1}$, Sarah Boyd ${ }^{1}$, Christina Bracamontes ${ }^{1}$, Sheralyn Sanchez ${ }^{1}$, \\ Munmun Chattopadhyay ${ }^{2,3}$ and Alok Dwivedi $2,3,4$ (D) \\ 1 Department of Obstetrics and Gynecology, Texas Tech University Health Sciences Center El Paso, \\ El Paso, TX 79905, USA; sireesha.reddy@ttuhsc.edu (S.R.); sarboyd@ttuhsc.edu (S.B.); \\ christina.bracamontes@ttuhsc.edu (C.B.); sheralyn.sanchez@ttuhsc.edu (S.S.) \\ 2 Graduate School of Biomedical Sciences, Texas Tech University Health Sciences Center at El Paso, \\ El Paso, TX 79905, USA; munmun.chattopadhyay@ttuhsc.edu (M.C.); alok.dwivedi@ttuhsc.edu (A.D.) \\ 3 Department of Molecular and Translational Medicine, Texas Tech University Health Sciences Center El Paso, \\ El Paso, TX 79905, USA \\ 4 Division of Biostatistics \& Epidemiology, Department of Molecular and Translational Medicine, Paul L. Foster \\ School of Medicine, Texas Tech University Health Sciences Center El Paso, El Paso, TX 79905, USA \\ * Correspondence: paldubey@ttuhsc.edu
}

check for updates

Citation: Dubey, P.; Reddy, S.; Boyd, S.; Bracamontes, C.; Sanchez, S.; Chattopadhyay, M.; Dwivedi, A. Effect of Nutritional Supplementation on Oxidative Stress and Hormonal and Lipid Profiles in PCOS-Affected Females. Nutrients 2021, 13, 2938. https://doi.org/10.3390/nu13092938

Academic Editor: Karolina

Szewczyk-Golec

Received: 21 July 2021

Accepted: 16 August 2021

Published: 25 August 2021

Publisher's Note: MDPI stays neutral with regard to jurisdictional claims in published maps and institutional affiliations.

Copyright: (c) 2021 by the authors. Licensee MDPI, Basel, Switzerland This article is an open access article distributed under the terms and conditions of the Creative Commons Attribution (CC BY) license (https:// creativecommons.org/licenses/by/ $4.0 /)$.
Abstract: Polycystic ovary syndrome (PCOS) affects several reproductive and endocrine features in females and has a poorly understood etiology. Treatment strategies for PCOS are limited and are based primarily on diet and nutrient supplementation. Recent studies have recommended some nutrients such as vitamins, minerals and vitamin-like nutrients for the therapy for PCOS. Therefore, it is claimed that the cause of PCOS could be vitamin or mineral deficiency. This review provides a narrative on the effect of nutritional supplementation on oxidative stress induced in PCOS. Oxidative stress plays a formative role in PCOS pathophysiology. This article reviews oxidative stress, its markers, nutritional supplementation and clinical studies. We also aim to show the effect of nutritional supplementation on genes affecting hormonal and glucose-mediated pathways.

Keywords: nutrition; supplement; oxidative stress; PCOS; disease markers

\section{Introduction}

Polycystic ovary syndrome (PCOS) is a heterogeneous disorder leading to adverse health outcomes across all ages [1]. PCOS is the leading cause of anovulatory infertility and may also lead to major cardiovascular events [2,3]. PCOS is marked by hyperandrogenism and insulin resistance (IR) across all ages and ethnicities [4].

Oxidative stress has been recognized in various pathological disorders related to IR [5], obesity [6], PCOS [7], type 2 diabetes and cardiovascular diseases [8]. The development of oxidative stress occurs when there is a disproportion between the generation of free radicals and antioxidants in biological systems. This disproportion results in a negative equilibrium shift [9]. Free radicals interact with micro- and macromolecules in the body by oxidation and deleterious alterations that occur intra- and extracellularly [10]. Oxidative stress ensues, causing DNA and protein damage. Normal reactive oxygen species (ROS) participate in embryonic processes involving fetal and placental development along with normal oocyte maturation and folliculogenesis [11], whereas excessive oxidative stress can result in fetal growth restriction (FGR), miscarriages or fetal death.

In the disease states associated with oxidative stress, hyperglycemia and increased free fatty acids induce the generation of ROS and impair insulin action. Factors in PCOS that increase oxidative stress are obesity, IR and hyperglycemia; however, non-obese PCOS women without IR are also reported to have increased oxidant status, suggesting that other factors may contribute to inducing the production of ROS in these women. Although the role of oxidative stress in PCOS pathogenesis in unclear, studies show that insulin 
resistance and oxidative stress cause an interplay affecting PCOS pathophysiology. In this article, we aim to explore the relationship between vitamin supplementation and PCOS-related symptoms.

\section{Oxidative Stress in PCOS}

Abnormal oxidation status can be correlated with diabetes, cardiovascular diseases, PCOS and cancer. OS impacts PCOS pathogenesis leading to insulin resistance, androgen excess and chronic inflammation. Primary circulating markers of oxidative stress include homocysteine, malondialdehyde (MDA), asymmetric dimethylarginine (AMDA), superoxide dismutase (SOD), glutathione (GSH), and paraoxonase 1 (PON1) [10]. Women with PCOS have abnormal levels of circulating biomarkers of OS. The imbalance in the total serum antioxidant level in women with PCOS exaggerates the cellular injury and decreases defense mechanisms. Oxidative stress is affected both by genetic and environmental factors. Increased ROS production potentially disrupts mitochondrial DNA (mtDNA) and induces cell apoptosis. Single-point mutations of genes encoding mitochondrial transfer RNA (mt-tRNA) associated with metabolic complications of PCOS, such as diabetes and hypertension, have been found in some studies [12].

\section{Markers of Oxidative Stress}

The pathogenesis of PCOS can be well studied by observing the biomarkers MDA, $\mathrm{NO}$, and the anti-oxidative biomarkers, primarily TAC, SOD, glutathione peroxidase (GPx) and glutathione stimulating hormone (GSH). The role of oxidative stress and antioxidant biomarkers is to estimate the risk of PCOS severity and cardiovascular events.

\subsection{Malondialdehyde}

Lipid peroxidation of polyunsaturated fatty acids generates malondialdehyde [13]. Murri et al. performed a meta-analysis to show increased levels of MDA concentrations in PCOS females compared to controls [10]. Kuscu et al. and Zhang et al. showed that MDA levels were increased in PCOS patients but were independent of obesity $[9,14]$. Dursun et al. compared PCOS patients with BMI and smoking status-matched controls and found similar serum MDA levels [15].

\subsection{Nitric Oxide}

NO (Nitric Oxide) is biosynthesized by various nitric oxide synthase (NOS) enzymes from L-arginine, oxygen and nicotinamide adenine dinucleotide phosphate and plays a significant role in cellular signaling. Monocytes, macrophages and neutrophils also synthesize small amounts of NO in immune responses. Murri et al. found no statistically significant differences in NO levels in PCOS subjects vs. controls [10]. Ovaries of Wistar rats treated with L-arginine, an NO precursor, had polycystic characteristics which emphasized the role of NO in the pathophysiology of PCOS [16]. Willis et al. compared NO metabolites in PCOS patients and age/BMI matched controls, showing similar nitrite but lower nitrate levels (nitrite/nitrate ratio = endothelium NO concentration) in PCOS patients (Nacul et al. suggested that $\mathrm{NO}$ was associated with insulin resistance in PCOS patients [17].

\subsection{Total Antioxidant Capacity}

Total antioxidant capacity (TAC) estimates the antioxidant response against the free radicals produced in a given disease. Murri et al. meta-analysis showed that TAC levels were similar in PCOS subjects and controls [10]. Fenkci et al. demonstrated that TAC levels were significantly lower in PCOS patients compared to BMI and smoking status-matched controls [18], contrary to Verit et al. who reported higher TAC levels in PCOS patients compared with age and BMI-matched controls. Due to the incongruous nature of the studies, further studies should be conducted to clarify the PCOS-antioxidants interconnection. 


\subsection{Reduced Glutathione (GSH)}

Glutathione is an antioxidant produced by the cells to withstand oxidative stress. Glutathione exists in a ratio of reduced (GSH) and oxidized forms (GSSG) to maintain homeostasis [19]. GSH plays an important role in the regulation of the disulfide bonds of proteins and the disposing of electrophiles and oxidants.

Murri et al. revealed that mean GSH levels were $50 \%$ lower in women with PCOS than in controls [10], similar to the studies conducted by Sabuncu et al. [20] and Dincer et al. citing the role of increased production of ROS in GSH depletion [21].

\section{Role of Supplementation in PCOS and Associated Comorbidities}

Nutritional supplementation plays a major role in PCOS-related oxidative stress and its associated comorbidities. Over the years, several authors have published a variety of nutritional supplements (Table 1 ) to alleviate oxidative stress and its associated adverse effects on the hormonal and lipid profiles of females (Table 2).

Table 1. Studies performed on supplementation in human and mice models.

\begin{tabular}{|c|c|c|c|c|c|c|}
\hline $\begin{array}{l}\text { Supplement } \\
\text { Composition }\end{array}$ & Year & Country & $\begin{array}{l}\text { Animal/Human } \\
\text { Studies }\end{array}$ & $\begin{array}{l}\text { Number of Pa- } \\
\text { tients/Animals }\end{array}$ & $\begin{array}{l}\text { Age } \\
\text { Group }\end{array}$ & Type of Study \\
\hline $\begin{array}{c}\text { Folate } \\
\text { supplementation [22] }\end{array}$ & 2014 & Iran & Human & 69 & $18-40$ & $\begin{array}{l}\text { Randomized, double-blind, } \\
\text { placebo-controlled }\end{array}$ \\
\hline $\begin{array}{c}\text { Omega-3 fatty acids and } \\
\text { vitamin E [23] }\end{array}$ & 2017 & Iran & Human & 68 & $18-40$ & $\begin{array}{c}\text { Randomized double-blind, } \\
\text { placebo-controlled }\end{array}$ \\
\hline $\begin{array}{l}\text { Flaxseed oil omega-3 } \\
\text { fatty acids [24] }\end{array}$ & 2017 & Iran & Human & 60 & $18-40$ & $\begin{array}{c}\text { Randomized double-blind, } \\
\text { placebo-controlled }\end{array}$ \\
\hline $\begin{array}{l}\text { Fish oil omega-3 fatty } \\
\text { acid [25] }\end{array}$ & 2018 & Iran & Human & 60 & $18-40$ & $\begin{array}{l}\text { Randomized double-blind, } \\
\text { placebo-controlled trial }\end{array}$ \\
\hline Vitamin E [26] & 2020 & China & Human & 321 & & $\begin{array}{l}\text { Retrospective cohort } \\
\text { clinical trial }\end{array}$ \\
\hline Alpha lipoic acid [27] & 2010 & USA & Human & 6 & $23-34$ & NR \\
\hline $\begin{array}{c}\text { Carnitine } \\
\text { supplementation [28] }\end{array}$ & 2017 & Iran & Human & 60 & $18-40$ & $\begin{array}{l}\text { Randomized, double-blind, } \\
\text { placebo-controlled trial }\end{array}$ \\
\hline $\begin{array}{c}\text { Selenium } \\
\text { supplementation [29] }\end{array}$ & 2017 & Poland & Human & 59 & $14-18$ & NR \\
\hline $\begin{array}{c}\text { Selenium } \\
\text { supplementation [30] }\end{array}$ & 2015 & Iran & Human & 64 & $18-40$ & $\begin{array}{c}\text { Randomized double-blind, } \\
\text { placebo-controlled }\end{array}$ \\
\hline $\begin{array}{c}\text { Selenium } \\
\text { supplementation [31] }\end{array}$ & 2016 & Iran & Human & 53 & $18-42$ & $\begin{array}{l}\text { Randomized, double-blind } \\
\text { and placebo-controlled } \\
\text { trial }\end{array}$ \\
\hline $\begin{array}{l}\text { Probiotic and selenium } \\
\text { co-supplementation [32] }\end{array}$ & 2018 & Iran & Human & 60 & $18-40$ & $\begin{array}{c}\text { Randomized, } \\
\text { double-blinded, } \\
\text { placebo-controlled clinical } \\
\text { trial }\end{array}$ \\
\hline $\begin{array}{c}\text { Selenium } \\
\text { supplementation [33] }\end{array}$ & 2015 & Iran & Human & 70 & $18-40$ & $\begin{array}{c}\text { Randomized, double-blind, } \\
\text { placebo-controlled trial }\end{array}$ \\
\hline Soy isoflavones [34] & 2018 & Iran & Human & 70 & $18-40$ & $\begin{array}{c}\text { Randomized, double-blind, } \\
\text { placebo-controlled trial }\end{array}$ \\
\hline $\begin{array}{c}\text { Synbiotic } \\
\text { supplementation [35] }\end{array}$ & 2018 & Iran & Human & 60 & & $\begin{array}{l}\text { Randomized, double-blind, } \\
\text { placebo-controlled trial }\end{array}$ \\
\hline Dietary soy [36] & 2018 & Iran & Human & 60 & $18-40$ & $\begin{array}{l}\text { Randomized, double-blind, } \\
\text { placebo-controlled trial }\end{array}$ \\
\hline
\end{tabular}


Table 1. Cont.

\begin{tabular}{|c|c|c|c|c|c|c|}
\hline $\begin{array}{l}\text { Supplement } \\
\text { Composition }\end{array}$ & Year & Country & $\begin{array}{l}\text { Animal/Human } \\
\text { Studies }\end{array}$ & $\begin{array}{l}\text { Number of Pa- } \\
\text { tients/Animals }\end{array}$ & $\begin{array}{l}\text { Age } \\
\text { Group }\end{array}$ & Type of Study \\
\hline $\begin{array}{c}\text { Probiotic } \\
\text { supplementation [37] }\end{array}$ & 2018 & Iran & Human & 60 & $18-40$ & $\begin{array}{l}\text { Randomized, double-blind, } \\
\text { placebo-controlled trial }\end{array}$ \\
\hline $\begin{array}{c}\text { Vitamin D-K-calcium } \\
\text { co-Supplementation } \\
{[38]}\end{array}$ & 2016 & Iran & Human & 60 & $18-40$ & $\begin{array}{l}\text { Randomized, double-blind, } \\
\text { placebo-controlled trial }\end{array}$ \\
\hline Vitamin D [39] & 2017 & Iran & Human & 60 & $20-40$ & Case-control study \\
\hline $\begin{array}{l}\text { Vitamin D and evening } \\
\text { primrose oil [40] }\end{array}$ & 2017 & Iran & Human & 60 & $18-40$ & $\begin{array}{l}\text { Randomized double-blind, } \\
\text { placebo-controlled trial }\end{array}$ \\
\hline $\begin{array}{c}\text { Vitamin D and } \\
\text { omega-3 } \\
\text { co-supplementation } \\
{[41]}\end{array}$ & 2018 & Iran & Human & 60 & $18-40$ & $\begin{array}{l}\text { Randomized double-blind, } \\
\text { placebo-controlled trial }\end{array}$ \\
\hline $\begin{array}{c}\text { Vitamin D and } \\
\text { probiotic } \\
\text { co-supplementation } \\
{[42]}\end{array}$ & 2019 & Iran & Human & 60 & $18-40$ & $\begin{array}{l}\text { Randomized double-blind, } \\
\text { placebo-controlled trial }\end{array}$ \\
\hline $\begin{array}{c}\text { MitoQ10 and vitamin } \\
\text { D3 [43] }\end{array}$ & 2020 & Iran & Mouse & 48 & & NR \\
\hline Vitamin D [44] & 2021 & Iran & Mouse & 40 & & NR \\
\hline
\end{tabular}

Table 2. Effect of supplementation on clinical and laboratory features in human subjects.

\begin{tabular}{|c|c|c|c|c|c|}
\hline Supplement & Dosage & Hormonal Changes & $\begin{array}{l}\text { Changes in Lipid } \\
\text { Profile }\end{array}$ & $\begin{array}{c}\text { Changes in } \\
\text { Oxidative Stress } \\
\text { Markers }\end{array}$ & Genes Affected \\
\hline Folate [22] & $5 \mathrm{mg} / \mathrm{d}$ for 8 weeks & & & $\begin{array}{l}\downarrow \text { Plasma Hcy, MDA, } \\
\text { serum hs-CRP; } \\
\uparrow \text { plasma TAC and } \\
\text { total GSH levels }\end{array}$ & \\
\hline $\begin{array}{l}\text { Omega-3 fatty acids } \\
\text { and vitamin E [25] }\end{array}$ & $\begin{array}{l}\text { Co-supplementation } \\
\text { for } 12 \text { weeks }\end{array}$ & & $\begin{array}{c}\downarrow \text { Serum TGA, VLDL, } \\
\text { LDL- and total-/HDL } \\
\text { cholesterol in PCOS } \\
\text { subjects }\end{array}$ & $\begin{array}{c}\uparrow \text { Plasma TAC levels, } \\
\downarrow \text { malondialdehyde } \\
\text { levels }\end{array}$ & $\begin{array}{l}\text { Gene expression of } \\
L p(a) \text { and Ox-LDL }\end{array}$ \\
\hline $\begin{array}{l}\text { Flaxseed oil omega-3 } \\
\text { fatty acids [24] }\end{array}$ & $\begin{array}{l}\text { Supplementation } \\
\text { for } 12 \text { weeks }\end{array}$ & $\uparrow \mathrm{mFG}$ scores & $\begin{array}{l}\text { Beneficial effects on } \\
\text { insulin metabolism, } \\
\text { serum triglycerides, } \\
\text { VLDL-cholesterol } \\
\text { and hs-CRP levels }\end{array}$ & & \\
\hline $\begin{array}{l}\text { Fish oil omega-3 fatty } \\
\text { acid [25] }\end{array}$ & $\begin{array}{l}\text { Supplementation for } \\
12 \text { weeks }\end{array}$ & $\begin{array}{l}\text { Beneficial effects on } \\
\text { mental health } \\
\text { parameters, total } \\
\text { testosterone, } \\
\text { hirsutism }\end{array}$ & $\begin{array}{c}\text { Effective on insulin } \\
\text { markers }\end{array}$ & $\begin{array}{l}\downarrow \text { Inflammatory } \\
\text { markers and } \\
\text { oxidative stress }\end{array}$ & \\
\hline Vitamin E [26] & $100 \mathrm{mg} / \mathrm{d}$ & $\begin{array}{l}\text { No significant } \\
\text { differences of } \\
\text { ovulation rate, } \\
\text { clinical pregnancy } \\
\text { rate and ongoing } \\
\text { pregnancy rate }\end{array}$ & & $\downarrow$ Oxidative stress & \\
\hline Alpha lipoic acid [27] & $\begin{array}{l}600 \mathrm{mg} \text { twice daily } \\
\text { for } 16 \text { weeks }\end{array}$ & & & $\begin{array}{l}\text { No improvement in } \\
\text { serum oxidative } \\
\text { stress markers }\end{array}$ & \\
\hline
\end{tabular}


Table 2. Cont.

\begin{tabular}{|c|c|c|c|c|c|}
\hline Supplement & Dosage & Hormonal Changes & $\begin{array}{c}\text { Changes in Lipid } \\
\text { Profile }\end{array}$ & $\begin{array}{c}\text { Changes in } \\
\text { Oxidative Stress } \\
\text { Markers } \\
\end{array}$ & Genes Affected \\
\hline $\begin{array}{c}\text { Carnitine and } \\
\text { chromium co- } \\
\text { supplementation [28] }\end{array}$ & $\begin{array}{l}1000 \mathrm{mg} / \mathrm{d} \text { carnitine } \\
\text { plus } 200 \mathrm{mg} / \mathrm{d} \\
\text { chromium as } \\
\text { chromium picolinate } \\
\text { for } 12 \text { weeks }\end{array}$ & $\begin{array}{l}\downarrow \text { Total testosterone } \\
\text { and hirsutism }\end{array}$ & & $\begin{array}{c}\downarrow \text { Malondialdehyde } \\
\text { (MDA) levels and } \\
\text { higher total } \\
\text { antioxidant capacity } \\
\text { (TAC) }\end{array}$ & $\begin{array}{c}\uparrow \text { Gene expression of } \\
\text { interleukin- } 6 \text { (IL-6) } \\
\text { and tumor necrosis } \\
\text { factor alpha (TNF-a) }\end{array}$ \\
\hline $\begin{array}{c}\text { Melatonin } \\
\text { supplementation [45] }\end{array}$ & $\begin{array}{l}5 \text { mg melatonin } \\
\text { supplements }\end{array}$ & $\begin{array}{l}\downarrow \text { Hirsutism, serum } \\
\text { total testosterone }\end{array}$ & & $\begin{array}{c}\downarrow \text { Malondialdehyde } \\
\text { (MDA) levels, } \\
\uparrow \text { plasma total } \\
\text { antioxidant capacity } \\
\text { (TAC) levels and total } \\
\text { glutathione (GSH) }\end{array}$ & $\begin{array}{c}\downarrow \text { Gene expression of } \\
\text { IL-1, (TNF- } \alpha)\end{array}$ \\
\hline $\begin{array}{c}\text { Curcumin } \\
\text { supplementation [46] }\end{array}$ & $\begin{array}{l}1500 \mathrm{mg} / \mathrm{d} \text { Curcumin } \\
\text { for } 12 \text { weeks }\end{array}$ & & & $\begin{array}{l}\uparrow \text { Serum activity of } \\
\text { GPx }\end{array}$ & $\begin{array}{l}\uparrow \text { SIRT1 gene } \\
\text { expression }\end{array}$ \\
\hline $\begin{array}{c}\text { Selenium } \\
\text { supplementation [30] }\end{array}$ & $\begin{array}{l}200 \mu \mathrm{g} \text { selenium per } \\
\text { day for } 8 \text { weeks }\end{array}$ & $\begin{array}{c}\uparrow \text { Pregnancy rate, } \\
\downarrow \text { Alopecia and acne, } \\
\downarrow \text { Serum (DHEAS), } \\
\text { hirsutism (modified } \\
\text { Ferriman-Gallwey } \\
\text { scores) }\end{array}$ & & & \\
\hline $\begin{array}{c}\text { Probiotic and } \\
\text { selenium co- } \\
\text { supplementation [32] }\end{array}$ & $\begin{array}{c}8 \times 10^{9} \mathrm{CFU} / \mathrm{d} \\
\text { probiotic } \\
200 \mu \mathrm{g} / \mathrm{d}\end{array}$ & $\begin{array}{c}\downarrow \text { Total testosterone, } \\
\text { hirsutism }\end{array}$ & & $\begin{array}{c}\text { MDA levels, } \\
\uparrow \text { TAC and GSH } \\
\text { levels }\end{array}$ & \\
\hline $\begin{array}{l}\text { Selenium } \\
\text { supplementation [29] }\end{array}$ & $\begin{array}{c}200 \mathrm{mcg} / \mathrm{d} \text { for } 8 \\
\text { weeks }\end{array}$ & & $\begin{array}{l}\downarrow \text { Serum triglycerides } \\
\text { and VLDL-C } \\
\text { concentrations }\end{array}$ & $\begin{array}{c}\downarrow \text { Serum insulin } \\
\text { levels, homeostasis } \\
\text { model of } \\
\text { assessment-insulin } \\
\text { resistance } \\
\text { (HOMA-IR), } \\
\text { (HOMA-B); } \\
\text { quantitative insulin } \\
\text { sensitivity check } \\
\text { index (QUICKI) }\end{array}$ & \\
\hline Soy isoflavones [34] & $\begin{array}{c}50 \mathrm{mg} / \mathrm{d} \text { soy } \\
\text { isoflavones for } 12 \\
\text { weeks }\end{array}$ & $\begin{array}{c}\downarrow \text { Circulating serum } \\
\text { levels of insulin and } \\
\text { HOMA-IR, } \\
\uparrow \text { quantitative insulin } \\
\text { sensitivity check } \\
\text { index, } \\
\downarrow \text { free androgen } \\
\text { index and serum } \\
\text { triglycerides, } \\
\uparrow \text { plasma total } \\
\text { glutathione } \downarrow \downarrow \text { malondial }\end{array}$ & $\begin{array}{l}\downarrow \text { Free androgen } \\
\text { index and serum } \\
\text { triglycerides }\end{array}$ & $\begin{array}{c}\downarrow \text { Circulating serum } \\
\text { levels of insulin and } \\
\text { HOMA-IR, } \\
\uparrow \text { Quantitative } \\
\text { insulin sensitivity } \\
\text { check index, } \\
\uparrow \text { Plasma total } \\
\text { glutathione } \\
\downarrow \text { Malondialdehyde } \\
\text { levels }\end{array}$ & \\
\hline $\begin{array}{c}\text { Synbiotic } \\
\text { supplementation [35] }\end{array}$ & $\begin{array}{c}\text { Synbiotic } \\
\text { supplements } \\
\text { containing } \\
\text { Lactobacillus } \\
\text { acidophilus, } \\
\text { Lactobacillus casei } \\
\text { and Bifidobacterium } \\
\text { bifidum }\end{array}$ & $\begin{array}{c}\uparrow \text { (SHBG), plasma } \\
\text { NO, } \\
\downarrow \text { modified } \\
\text { Ferriman-Gallwey } \\
\text { (mFG) scores and } \\
\text { serum hs-CRP }\end{array}$ & & & \\
\hline Dietary soy [36] & $\begin{array}{l}0.8 \text { g protein } \mathrm{kg}^{-1} \\
\text { body weight }(35 \% \\
\text { animal proteins, } 35 \% \\
\text { soy protein and } 30 \% \\
\text { vegetable proteins) }\end{array}$ & $\begin{array}{l}\downarrow \text { Total testosterone, } \\
\quad \downarrow \text { triglycerides }\end{array}$ & $\begin{array}{l}\downarrow \text { Triglycerides, body } \\
\text { mass index (BMI), } \\
\text { fasting plasma } \\
\text { glucose, insulin and } \\
\text { insulin resistance; } \uparrow \\
\text { quantitative insulin } \\
\text { sensitivity check } \\
\text { index }\end{array}$ & $\begin{array}{c}\downarrow \mathrm{MDA}, \uparrow \mathrm{NO} \text { and } \\
\text { GSH }\end{array}$ & \\
\hline
\end{tabular}


Table 2. Cont.

\begin{tabular}{|c|c|c|c|c|c|}
\hline Supplement & Dosage & Hormonal Changes & $\begin{array}{l}\text { Changes in Lipid } \\
\text { Profile }\end{array}$ & $\begin{array}{c}\text { Changes in } \\
\text { Oxidative Stress } \\
\text { Markers }\end{array}$ & Genes Affected \\
\hline $\begin{array}{c}\text { Probiotic } \\
\text { supplementation [47] }\end{array}$ & $\begin{array}{c}\text { Lactobacillus } \\
\text { acidophilus, } \\
\text { Lactobacillus casei } \\
\text { and Bifidobacterium } \\
\text { bifidum }\left(2 \times 10^{9}\right. \\
\text { CFU/g each) for } 12 \\
\text { weeks }\end{array}$ & $\begin{array}{c}\uparrow \text { Serum SHBG and } \\
\text { plasma TAC; } \\
\downarrow \text { serum total } \\
\text { testosterone, mFG } \\
\text { scores, serum hs-CRP } \\
\text { and plasma MDA }\end{array}$ & & $\begin{array}{l}\uparrow \text { Plasma TAC, } \\
\downarrow \text { plasma MDA }\end{array}$ & \\
\hline $\begin{array}{l}\text { Vitamin D-K-calcium } \\
\text { co- } \\
\text { supplementation [38] }\end{array}$ & $\begin{array}{l}200 \text { IU vitamin D, } 90 \\
\mu g \text { vitamin K plus, } \\
500 \text { mg calcium } \\
\text { supplements for } 8 \\
\text { weeks }\end{array}$ & $\begin{array}{c}\downarrow \text { Serum-free } \\
\text { testosterone, } \\
\downarrow \text { luteinizing } \\
\text { hormone }\end{array}$ & & $\begin{array}{l}\uparrow \text { Plasma TAC, } \\
\downarrow \text { plasma MDA }\end{array}$ & \\
\hline Vitamin D [48] & $\begin{array}{l}4000 \text { IU vitamin D or } \\
1000 \text { IU of vitamin D } \\
\text { for } 12 \text { weeks }\end{array}$ & $\begin{array}{l}\downarrow \text { Total testosterone, } \\
\text { free androgen index } \\
\text { (FAI), hirsutism; } \\
\uparrow \text { mean change in } \\
\text { SHBG }\end{array}$ & & $\begin{array}{l}\uparrow \text { Total antioxidant } \\
\text { capacity (TAC) }\end{array}$ & \\
\hline Vitamin D [49] & 50,000 IU Vitamin D & & $\begin{array}{c}\downarrow \text { FPG, insulin, } \\
\text { HOMA-IR, estimated } \\
\text { B cell function; } \\
\uparrow \text { quantitative insulin } \\
\text { sensitivity check } \\
\text { index }\end{array}$ & $\begin{array}{c}\downarrow \text { Plasma } \\
\text { malondialdehyde } \\
\text { (MDA) levels }\end{array}$ & \\
\hline Vitamin D and [40] & $\begin{array}{c}1000 \text { IU vitamin D3 } \\
\text { plus } 1000 \text { mg Vitamin } \\
\text { E }\end{array}$ & & $\begin{array}{c}\downarrow \text { Triglycerides, very } \\
\text { low-density } \\
\text { lipoprotein (VLDL) } \\
\text { cholesterol levels }\end{array}$ & $\begin{array}{c}\uparrow \text { Serum } 25(\mathrm{OH}) \mathrm{D} \\
\text { and plasma GSH, } \\
\downarrow \text { MDA }\end{array}$ & \\
\hline $\begin{array}{c}\text { Vitamin D and } \\
\text { omega-3 co- } \\
\text { supplementation [41] }\end{array}$ & $\begin{array}{c}50,000 \text { IU vitamin D } \\
\text { every } 2 \text { weeks plus } \\
2000 \mathrm{mg} / \mathrm{d} \text { omega-3 } \\
\text { fatty acid from fish } \\
\text { oil }\end{array}$ & $\begin{array}{c}\downarrow \text { Serum total } \\
\text { testosterone levels; } \uparrow \\
\text { Beck depression } \\
\text { inventory, general } \\
\text { health questionnaire } \\
\text { scores and } \\
\text { depression anxiety } \\
\text { and stress scale } \\
\text { scores }\end{array}$ & & $\begin{array}{c}\downarrow \text { Serum hs-CRP and } \\
\text { MDA, } \\
\uparrow \text { TAC compared } \\
\text { with the placebo }\end{array}$ & $\begin{array}{c}\downarrow \text { Gene expression of } \\
\text { (IL-1) and (VEGF) }\end{array}$ \\
\hline $\begin{array}{c}\text { Vitamin D and } \\
\text { probiotic co- } \\
\text { supplementation [42] }\end{array}$ & $\begin{array}{c}50,000 \mathrm{IU} \text { vitamin } \mathrm{D} \\
\text { and } 8 \times 10^{9} \mathrm{CFU} / \mathrm{d} \\
\text { probiotic every } 2 \\
\text { weeks }\end{array}$ & $\downarrow$ Total testosterone & & $\begin{array}{c}\downarrow \text { MDA, } \\
\uparrow \mathrm{TAC} \text { and GSH }\end{array}$ & \\
\hline $\begin{array}{l}\text { MitoQ10 and Vitamin } \\
\text { D3 [43] }\end{array}$ & & $\begin{array}{l}\downarrow \text { Estradiol, } \\
\text { progesterone, FSH, } \\
\text { LH, LH/FSH }\end{array}$ & & $\downarrow$ MDA and SOD & $\begin{array}{c}\downarrow \text { mRNAs of } 3 \beta-\mathrm{HSD}, \\
\text { Cyp19a1, Cyp11a1, } \\
\text { StAR, Keap1, HO-1 } \\
\text { and Nrf2 }\end{array}$ \\
\hline
\end{tabular}

Abbreviations: FSH: follicle-stimulating hormone, LH: luteinizing hormone, MDA: malondialdehyde, SOD: superoxide dismutase, TAC: total antioxidant capacity, GSH: glutathione, (hs-CRP): high-sensitivity C-reactive protein, $(25(\mathrm{OH}) \mathrm{D})$ : 25-hydroxyvitamin D, HOMA-IR: homeostasis model of assessment-IR, VLDL: very low-density lipoprotein, SHBG: sex hormone binding globulin, FAI: free androgen index, FPG: fasting plasma glucose, mFG: modified Ferriman-Gallway, TGA: triglycerides, NO: nitric oxide, Hcy: homocysteine. $\downarrow$ depressed, $\uparrow$ elevated.

\subsection{Vitamin D}

The molecular mechanism between vitamin D and PCOS is unclear. Irani et al. reported improvement in the biochemical parameters of women with PCOS when supplemented with vitamin D3, suggesting that the inflammatory progress in the pathogenesis of PCOS may be prevented by vitamin D3. In contrast, Jafari-Sfidvajani et al. found no significant differences in androgen profiles after vitamin D supplementation except improvement in menstrual frequency [50]. A study by Krul-Poel et al. [51] confirmed the role of vitamin D in adverse metabolic events of PCOS. Another study concluded that obese PCOS women had significantly decreased 25-dehydroxy vitamin D levels [52]. Further, 
lower vitamin D levels were linked with insulin resistance owing to the complex pathophysiology of PCOS [53]. A meta-analysis conducted by Akbari et al. on seven randomized controlled trials (RCT) concluded that vitamin D supplementation in women with PCOS resulted in an improvement in high-sensitivity C-reactive protein (hs-CRP), malondialdehyde (MDA) and total antioxidant capacity (TAC) but did not affect nitric oxide (NO) and total glutathione (GSH) levels [49]. Another RCT with vitamin D-K-calcium showed a trend towards a decline in luteinizing hormone, whereas there was no significant effect of vitamin D-K-calcium co-supplementation on prolactin, follicle-stimulating hormone, 17-OH progesterone, inflammatory markers and glutathione levels [38]. In an RCT, the vitamin D and omega-3 fatty acid co-administration for 12 weeks had beneficial effects on mental health parameters, serum total testosterone (TT) levels, hs-CRP, TAC and MDA in women with PCOS [41]. In another meta-analysis study where reports of RCT and 956 subjects were identified, the results demonstrated that supplementation with vitamin D in PCOS patients improved TT, hs-CRP, TAC and MDA levels without affecting other hormonal and oxidative markers, primarily NO and GSH levels. Low-dose vitamin D supplementation $(\leq 1000 \mathrm{IU} /$ day) on a daily basis was more promising for improving hormones and oxidative stress in PCOS patients [54]. Our observation that vitamin D improves the levels of oxidative stress in PCOS is consistent with the meta-analysis studies of Xue [55] and Lagowska [48]. A study by Kyei et al. found that a combination of vitamin D3 and MitoQ10 significantly reduced the oxidative markers SOD and MDA and reduced the hormonal markers estradiol, progesterone, FSH, LH and LH/FSH. The study also observed an improvement in the histomorphological features of ovaries with many healthy follicles and few atretic follicles after co-administration [43].

\subsection{Flavonoids and Isoflavones}

Both flavonoids and isoflavones consist of polyphenols with antioxidant, antidiabetic and anti-inflammatory properties [56]. Oh et al. analyzed six flavonoid classes for treatment of metabolic syndrome in PCOS and found that only flavonol consumption was effective against metabolic syndrome in PCOS [17]. Romualdi et al. showed an improved lipid profile when administering $36 \mathrm{mg}$ per day of soy isoflavone genistein for 12 weeks to women with PCOS. They observed markedly improved total cholesterol and reduced LDL. No change was observed in anthropometric features, the hormonal milieu, menstrual cycles and overall glycoinsulinemic metabolism [57]. Another study observed the outcomes of a soy diet comprising of, i.e., $0.8 \mathrm{~g}$ of protein ( $35 \%$ animal proteins, $35 \%$ soy protein and $30 \%$ vegetable proteins) per $\mathrm{kg}^{-1}$ of body weight in which there was found to be a depletion in body mass index, TT, TGA and MDA levels, while the NO and GSH levels were found to be elevated compared to the controls [36]. Jamilian et al. explored the effects of soy isoflavones on metabolic status of PCOS patients and found that $50 \mathrm{mg}$ per day significantly decreased serum insulin and HOMA-IR, free androgen index, serum TGA and MDA and increased plasma total glutathione compared to the placebo group.

\subsection{Selenium}

Selenium (Se) is protective against oxidative stress [58] and is imperative for reproductive tissue formation [59]. High androgen levels, free radicals and insufficient selenium levels have been associated with women with PCOS [33]. Hajizadeh-Sharafabad et al. conducted a systematic review of seven studies and proposed that Se supplementation decreases the BMI and weight of PCOS patients [60]. Additionally, 200 micrograms ( $\mu \mathrm{g}$ ) per day of Se plus $8 \times 10^{9}$ colony forming units (CFU)/day probiotic supplementation in PCOS women for 12 weeks reduced body weight and cardio-metabolic adverse outcomes [32]. In contrast, Hosseinzadeh et al. indicated that women with PCOS administered with $200 \mu \mathrm{g} /$ day of Se for 12 weeks did not show weight change. They also indicated that the indiscriminate consumption of selenium may worsen insulin resistance in PCOS subjects [31]. The findings may be inconsistent due to differences in interventional duration, clinical features of subjects, levels of physical activity and diet. Additionally, Se affects insulin 
concentrations resulting in reduced body weight, reduced BMI, IGF (insulin-like growth factors) and their binding proteins. A study by Coskun et al. revealed that women with PCOS had lower serum levels of Se and increased insulin levels and HOMA-IR, but, when compared with the controls, the levels were not statistically significant [33]. Shabani et al. indicated that $200 \mu \mathrm{g} /$ day of Se and $8 \times 10^{9} \mathrm{CFU} /$ day probiotics co-supplementation for 12 weeks led to a significant reduction in weight, serum insulin levels and the homeostatic model of assessment for insulin resistance and a significant increase in the quantitative insulin sensitivity check index [61]. In addition, selenium and probiotic co-supplementation reduced serum triglycerides, total LDL and total-/HDL-cholesterol ratio compared with the placebo [61]. Similarly, Razavi et al. reported that $200 \mu \mathrm{g}$ of Se daily for 8 weeks reduced serum dehydroepiandrosterone (DHEA) levels, decreased acne and hirsutism, and caused higher pregnancy incidence when compared to the placebo [30].

\subsection{Probiotics}

Probiotics have a synergic relationship with gut microbiota, thus having a beneficial effect on metabolism [62-64]. Studies on probiotic consumption showed improvement in fasting blood glucose levels and antioxidant status in patients with type 2 diabetes [65] and delayed onset of glucose intolerance, hyperglycemia, hyperinsulinemia and dyslipidemia in diabetic rats [66]. Shoaei et al. found reduced fasting blood sugar and serum insulin levels but unaffected CRP in patients administered with multispecies probiotics for 8 weeks [67].

Inflammation and insulin resistance in PCOS is associated with the dysbiosis of gut microbiota (DOGMA) [68], which affects PCOS pathophysiology and insulin receptor function. Probiotic supplements are recommended to overcome dysbiosis [47]. Fecal microbiota transplantation (FMT) and lactobacillus transplantation in rats with PCOS showed that rats in the FMT group had improved estrous cycles, while most of the lactobacillus-treated rats showed decreased androgen biosynthesis [69].

Nasri et al. reported that synbiotic supplementation enhanced serum sex hormonebinding globulin (SHBG) and plasma NO and decreased modified Ferriman-Gallwey (mFG) scores, FAI, serum hs-CRP, serum insulin levels and HOMA-IR, while no significant effect was observed on hormonal status and biomarkers of oxidative stress [35].

\subsection{Vitamin E, Folate and Omega-3 Fatty Acids}

Vitamin $E$ is a free radical scavenger that synchronizes the oxidant/antioxidant ratio. Cicek et al. concluded in their study that vitamin E could improve features of endometrial lining in infertile women because of its anticoagulant and antioxidant effects [70].

Bahmani et al. showed supplementation of folate $(5 \mathrm{mg} /$ day) resulted in reduced plasma Hcy, HOMA-B, serum hs-CRP and plasma MDA concentrations and increased plasma TAC and GSH levels compared with the placebo groups [22].

Omega-3 fatty acids and vitamin E co-supplementation downregulated the gene expression of lipoprotein (a), mRNA and oxidized-LDL mRNA and significantly reduced serum TGA, VLDL, LDL- and total-/HDL cholesterol in PCOS subjects. Plasma TAC levels were increased with a marked decrease in malondialdehyde levels compared with the placebo group [23].

A study conducted by Mirmasoumi et al. in which flaxseed oil omega-3 supplementation was administered for 12 weeks significantly decreased insulin values, HOMA-IR and $\mathrm{mFG}$ scores and increased the quantitative insulin sensitivity check index. It also showed a decrease in serum TGA, VLDL-cholesterol and high-sensitivity C-reactive protein (hs-CRP) when compared to the placebo group. No significant effects were observed for flaxseed oil omega-3 supplementation on hormonal profiles, lipid profiles and plasma NO levels [24]. Omega-3 fatty acid intake was found to lead to significantly decreased serum insulin levels, HOMA-IR, TT and hirsutism while increasing the quantitative insulin sensitivity check index (QUICKI). It also reduced high sensitivity C-reactive protein and MDA and enhanced plasma total glutathione when compared to the placebo. Changes in other metabolic parameters were not observed [25]. 


\section{Inflammation in PCOS}

Insulin resistance, oxidative stress and inflammation are frequently tied to PCOS and also described as the risk factors for the development of metabolic syndrome [71]. A number of inflammatory mediators and chemokines also play important roles in the function of the various female reproductive organs [72,73]. Oxidative stress markers are often associated with increased inflammation. An elevated level of CRP is one of the distinct inflammatory markers that is observed in PCOS individuals, and this phenomenon is also abundantly found in patients with other metabolic syndromes [74]. Interleukin (IL)-18 and monocyte chemoattractant protein1 (MCP-1) are increased in patients with PCOS $[75,76]$. Patients with PCOS have shown elevated levels of white blood count (WBC) in many studies [77]. The recruitment and activation of leukocytes implemented by the involvement of chemokines such as C-C motif ligand 3 (CCL3) can also lead to metabolic syndrome in PCOS individuals [78]. PCOS and inflammation may be related to low-grade chronic infection. Endothelial inflammation along with markers of endothelial function such as endothelin-1 (ET-1), soluble intercellular adhesion molecule-1 (sICAM-1) and soluble vascular cell adhesion molecule 1 (sVCAM-1) have been found to be elevated in women with PCOS $[79,80]$, and women with PCOS and insulin resistance often showed endothelial dysfunction. Women with PCOS exhibited a state of chronic low-grade inflammation, which may help evaluate the changes in biomarkers and their association with cardiac complications.

\section{Effective vs. Less Effective Supplementation}

Significant markers of oxidative stress include: reduced levels of nitric oxide (NO), low total antioxidant capacity (TAC) and higher malondialdehyde (MDA). A meta-analysis by Chan Meng showed that PCOS was associated with serum/plasma nitrite levels. Furthermore, in patients with PCOS, serum or plasma nitrite levels were reduced compared with controls. Based on previous studies, it has been observed that synbiotic supplementation and dietary soy were beneficial in the overall improvement of nitric oxide (NO) levels in patients with PCOS, but other supplementation seemed to have no effect on NO levels. On the contrary, TAC and MDA levels were improved with carnitine supplementation with and without chromium, melatonin, dietary soy, probiotics and vitamin D supplementation. Selenium supplementation should be taken with caution as it may lead to an increased insulin resistance as shown by some studies. Hirsutism, being one of the major consequences of PCOS, was observed and measured in almost all these clinical trials. The supplements which had an overall favorable effect on hirsutism were melatonin supplementation, inositol and selenium supplementation with probiotics. Modified Ferriman $\neg-$ Gallaway (mFG) scores, another PCOS indicator observed in these studies, were significantly improved by probiotics and selenium supplementation. A sharp decline in levels of total testosterone was observed with omega-3 fatty acids, carnitine and chromium co-supplementation, melatonin, probiotics, selenium and vitamin $\mathrm{D}$. The studies that failed to show significant positive effects on the improvement of either symptoms or lipid and hormonal assay included supplementation of alpha lipoic acid, curcumin, vitamin E and hydroxysafflor yellow A.

\section{Effect on Gene Expression}

Some studies targeted the overall effect of supplements on targeted genes. Forty infertile PCOS subjects were administered $200 \mu \mathrm{g}$ selenium for 8 weeks which resulted in significantly increased expression levels of PPAR- $\gamma$ and GLUT- 1 and decreased expression levels of LDLR [81]. Omega-3 EPA in doses ranging 25-200 $\mu \mathrm{g}$ in granulosa cell cultures resulted in higher IGF-1 expression and lower COX2 expression, which is essential for follicular differentiation and oocyte maturation [82]. Curcumin supplementation significantly increased serum activity of GPx but was statistically insignificant for SIRT1 gene expression [46]. Gene expression of interleukin-1 (IL-1) and tumor necrosis factor alpha (TNF- $\alpha$ ) was significantly downregulated with melatonin supplementation in PCOS subjects vs. 
placebo [45]. Vitamin D MitoQ10 supplementation resulted in significantly low expression rates of mRNAs of 3ß-HSD, Cyp19a1, Cyp11a1, StAR, Keap1, HO-1 and Nrf2 [43].

\section{Conclusions}

To summarize, oxidative stress and antioxidant biomarkers can effectively modify the risk of PCOS severity and cardiovascular events in women. Simple nutritional supplements may offset these risks by counteracting the effects of oxidative stress on PCOS. Vitamin, minerals, probiotic supplements and other dietary additives can be significantly beneficial in reducing PCOS-related symptoms.

Author Contributions: Conceptualization, P.D. and S.R.; methodology, A.D.; software, none; validation, M.C., S.S., C.B.; formal analysis, Not applicable; investigation, P.D. and S.B.; resources, PubMed and Web of Science; data curation, C.B.; writing—original draft preparation, P.D.; writingreview and editing, P.D., A.D. and S.R.; visualization, A.D.; supervision, S.R.; project administration, P.D.; funding acquisition, None. All authors have read and agreed to the published version of the manuscript.

Funding: This research received no external funding.

Institutional Review Board Statement: Not applicable.

Informed Consent Statement: Not applicable.

Data Availability Statement: We used PubMed and web of science to screen articles for this narrative review. We did not report any data.

Conflicts of Interest: The authors declare no conflict of interest.

\section{References}

1. Saadia, Z. Follicle stimulating hormone (LH: FSH) ratio in polycystic ovary syndrome (PCOS)—Obese vs. non- obese women. Med. Arch. 2020, 74, 289-293. [CrossRef]

2. Dwivedi, A.K.; Dubey, P.; Cistola, D.P.; Reddy, S.Y. Association between obesity and cardiovascular outcomes: Updated evidence from meta-analysis studies. Curr. Cardiol. Rep. 2020, 22, 25. [CrossRef]

3. Azziz, R.; Carmina, E.; Dewailly, D.; Diamanti-Kandarakis, E.; Escobar-Morreale, H.F.; Futterweit, W.; Janssen, O.E.; Legro, R.S.; Norman, R.J.; Taylor, A.E.; et al. The androgen excess and PCOS society criteria for the polycystic ovary syndrome: The complete task force report. Fertil. Steril. 2009, 91, 456-488. [CrossRef]

4. Dubey, P.; Reddy, S.Y.; Alvarado, L.; Manuel, S.L.; Dwivedi, A.K. Prevalence of at-risk hyperandrogenism by age and race/ethnicity among females in the United States using NHANES III. Eur. J. Obstet. Gynecol. Reprod. Biol. 2021, 260, 189-197. [CrossRef]

5. Kellow, N.J.; Savige, G.S. Dietary advanced glycation end-product restriction for the attenuation of insulin resistance, oxidative stress and endothelial dysfunction: A systematic review. Eur. J. Clin. Nutr. 2013, 67, 239-248. [CrossRef]

6. Khan, N.I.; Naz, L.; Yasmeen, G. Obesity: An independent risk factor for systemic oxidative stress. Pak. J. Pharm. Sci. 2006, 19, 62-65.

7. Macut, D.; Bjekic-Macut, J.; Savic-Radojevic, A. Dyslipidemia and oxidative stress in PCOS. Front. Horm. Res. 2013, 40, 51-63. [CrossRef]

8. Cervantes Gracia, K.; Llanas-Cornejo, D.; Husi, H. CVD and oxidative stress. J. Clin. Med. 2017, 6, 22. [CrossRef] [PubMed]

9. Zhang, D.; Luo, W.Y.; Liao, H.; Wang, C.F.; Sun, Y. The effects of oxidative stress to PCOS. Sichuan Da Xue Xue Bao Yi Xue Ban 2008, 39, 421-423. [PubMed]

10. Murri, M.; Luque-Ramirez, M.; Insenser, M.; Ojeda-Ojeda, M.; Escobar-Morreale, H.F. Circulating markers of oxidative stress and polycystic ovary syndrome (PCOS): A systematic review and meta-analysis. Hum. Reprod. Update 2013, 19, 268-288. [CrossRef] [PubMed]

11. Mohammadi, M. Oxidative stress and polycystic ovary syndrome: A brief review. Int. J. Prev. Med. 2019, 10, 86. [CrossRef] [PubMed]

12. Zeng, X.; Huang, Q.; Long, S.L.; Zhong, Q.; Mo, Z. Mitochondrial dysfunction in polycystic ovary syndrome. DNA Cell Biol. 2020, 39, 1401-1409. [CrossRef] [PubMed]

13. Abuja, P.M.; Albertini, R. Methods for monitoring oxidative stress, lipid peroxidation and oxidation resistance of lipoproteins. Clin. Chim. Acta 2001, 306, 1-17. [CrossRef]

14. Kuscu, N.K.; Var, A. Oxidative stress but not endothelial dysfunction exists in non-obese, young group of patients with polycystic ovary syndrome. Acta Obstet. Gynecol. Scand. 2009, 88, 612-617. [CrossRef] [PubMed]

15. Dursun, P.; Demirtas, E.; Bayrak, A.; Yarali, H. Decreased serum paraoxonase 1 (PON1) activity: An additional risk factor for atherosclerotic heart disease in patients with PCOS? Hum. Reprod. 2006, 21, 104-108. [CrossRef] 
16. Hassani, F.; Karami, M.; Nadoushan, M.R.J.; Yazdi, P.E. Nitric oxide-induced polycystic ovaries in the wistar rat. Int. J. Fertil. Steril. 2012, 6, 111-116.

17. Oh, J.S.; Kim, H.; Vijayakumar, A.; Kwon, O.; Choi, Y.J.; Huh, K.B.; Chang, N. Association between dietary flavanones intake and lipid profiles according to the presence of metabolic syndrome in Korean women with type 2 diabetes mellitus. Nutr. Res. Pract. 2016, 10, 67-73. [CrossRef] [PubMed]

18. Fenkci, V.; Fenkci, S.; Yilmazer, M.; Serteser, M. Decreased total antioxidant status and increased oxidative stress in women with polycystic ovary syndrome may contribute to the risk of cardiovascular disease. Fertil. Steril. 2003, 80, 123-127. [CrossRef]

19. Marí, M.; Morales, A.; Colell, A.; García-Ruiz, C.; Fernández-Checa, J.C. Mitochondrial glutathione, a key survival antioxidant. Antioxid. Redox Signal. 2009, 11, 2685-2700. [CrossRef]

20. Sabuncu, T.; Vural, H.; Harma, M.; Harma, M. Oxidative stress in polycystic ovary syndrome and its contribution to the risk of cardiovascular disease. Clin. Biochem. 2001, 34, 407-413. [CrossRef]

21. Dinger, Y.; Akcay, T.; Erdem, T.; Ilker Saygili, E.; Gundogdu, S. DNA damage, DNA susceptibility to oxidation and glutathione level in women with polycystic ovary syndrome. Scand. J. Clin. Lab. Investig. 2005, 65, 721-728. [CrossRef]

22. Bahmani, F.; Karamali, M.; Shakeri, H.; Asemi, Z. The effects of folate supplementation on inflammatory factors and biomarkers of oxidative stress in overweight and obese women with polycystic ovary syndrome: A randomized, double-blind, placebocontrolled clinical trial. Clin. Endocrinol. 2014, 81, 582-587. [CrossRef] [PubMed]

23. Rahmani, E.; Samimi, M.; Ebrahimi, F.A.; Foroozanfard, F.; Ahmadi, S.; Rahimi, M.; Jamilian, M.; Aghadavod, E.; Bahmani, F.; Taghizadeh, M.; et al. The effects of omega-3 fatty acids and vitamin E co-supplementation on gene expression of lipoprotein(a) and oxidized low-density lipoprotein, lipid profiles and biomarkers of oxidative stress in patients with polycystic ovary syndrome. Mol. Cell Endocrinol. 2017, 439, 247-255. [CrossRef]

24. Mirmasoumi, G.; Fazilati, M.; Foroozanfard, F.; Vahedpoor, Z.; Mahmoodi, S.; Taghizadeh, M.; Esfeh, N.K.; Mohseni, M.; Karbassizadeh, H.; Asemi, Z. The effects of flaxseed oil omega-3 fatty acids supplementation on metabolic status of patients with polycystic ovary syndrome: A randomized, double-blind, placebo-controlled trial. Exp. Clin. Endocrinol. Diabetes 2018, 126, 222-228. [CrossRef] [PubMed]

25. Amini, M.; Bahmani, F.; Foroozanfard, F.; Vahedpoor, Z.; Ghaderi, A.; Taghizadeh, M.; Karbassizadeh, H.; Asemi, Z. The effects of fish oil omega-3 fatty acid supplementation on mental health parameters and metabolic status of patients with polycystic ovary syndrome: A randomized, double-blind, placebo-controlled trial. J. Psychosom. Obstet. Gynaecol. 2018, 12, 2000. [CrossRef] [PubMed]

26. Chen, J.; Guo, Q.; Pei, Y.H.; Ren, Q.L.; Chi, L.; Hu, R.K.; Tan, Y. Effect of a short-term vitamin E supplementation on oxidative stress in infertile PCOS women under ovulation induction: A retrospective cohort study. BMC Womens Health 2020, 20, 69. [CrossRef]

27. Masharani, U.; Gjerde, C.; Evans, J.L.; Youngren, J.F.; Goldfine, I.D. Effects of controlled-release alpha lipoic acid in lean, nondiabetic patients with polycystic ovary syndrome. J. Diabetes Sci. Technol. 2010, 4, 359-364. [CrossRef]

28. Jamilian, H.; Jamilian, M.; Samimi, M.; Afshar Ebrahimi, F.; Rahimi, M.; Bahmani, F.; Aghababayan, S.; Kouhi, M.; Shahabbaspour, S.; Asemi, Z. Oral carnitine supplementation influences mental health parameters and biomarkers of oxidative stress in women with polycystic ovary syndrome: A randomized, double-blind, placebo-controlled trial. Gynecol. Endocrinol. 2017, 33, 442-447. [CrossRef]

29. Zagrodzki, P.; Krzyczkowska-Sendrakowska, M.; Nicol, F.; Wietecha-Posluszny, R.; Milewicz, T.; Kryczyk-Koziol, J.; Chaykivska, Z.; Jach, R. Selenium status parameters in patients with polycystic ovary syndrome. J. Trace Elem. Med. Biol. 2017, 44, 241-246. [CrossRef]

30. Razavi, M.; Jamilian, M.; Kashan, Z.F.; Heidar, Z.; Mohseni, M.; Ghandi, Y.; Bagherian, T.; Asemi, Z. Selenium supplementation and the effects on reproductive outcomes, biomarkers of inflammation, and oxidative stress in women with polycystic ovary syndrome. Horm. Metab. Res. 2016, 48, 185-190. [CrossRef]

31. Hosseinzadeh, F.M.; Hosseinzadeh-Attar, M.J.; Yekaninejad, M.S.; Rashidi, B. Effects of selenium supplementation on glucose homeostasis and free androgen index in women with polycystic ovary syndrome: A randomized, double blinded, placebo controlled clinical trial. J. Trace Elem. Med. Biol. 2016, 34, 56-61. [CrossRef]

32. Jamilian, M.; Mansury, S.; Bahmani, F.; Heidar, Z.; Amirani, E.; Asemi, Z. The effects of probiotic and selenium co-supplementation on parameters of mental health, hormonal profiles, and biomarkers of inflammation and oxidative stress in women with polycystic ovary syndrome. J. Ovarian Res. 2018, 11, 80. [CrossRef] [PubMed]

33. Coskun, A.; Arikan, T.; Kilinc, M.; Arikan, D.C.; Ekerbicer, H.C. Plasma selenium levels in Turkish women with polycystic ovary syndrome. Eur. J. Obstet. Gynecol. Reprod. Biol. 2013, 168, 183-186. [CrossRef]

34. Jamilian, M.; Asemi, Z. The effects of soy isoflavones on metabolic status of patients with polycystic ovary syndrome. J. Clin. Endocrinol. Metab. 2016, 101, 3386-3394. [CrossRef]

35. Nasri, K.; Jamilian, M.; Rahmani, E.; Bahmani, F.; Tajabadi-Ebrahimi, M.; Asemi, Z. The effects of synbiotic supplementation on hormonal status, biomarkers of inflammation and oxidative stress in subjects with polycystic ovary syndrome: A randomized, double-blind, placebo-controlled trial. BMC Endocr. Disord. 2018, 18, 21. [CrossRef] [PubMed]

36. Karamali, M.; Kashanian, M.; Alaeinasab, S.; Asemi, Z. The effect of dietary soy intake on weight loss, glycaemic control, lipid profiles and biomarkers of inflammation and oxidative stress in women with polycystic ovary syndrome: A randomised clinical trial. J. Hum. Nutr. Diet 2018, 31, 533-543. [CrossRef] 
37. Karamali, M.; Eghbalpour, S.; Rajabi, S.; Jamilian, M.; Bahmani, F.; Tajabadi-Ebrahimi, M.; Keneshlou, F.; Mirhashemi, S.M.; Chamani, M.; Hashem Gelougerdi, S.; et al. Effects of probiotic supplementation on hormonal profiles, biomarkers of inflammation and oxidative stress in women with polycystic ovary syndrome: A randomized, double-blind, placebo-controlled trial. Arch. Iran. Med. 2018, 21, 1-7. [PubMed]

38. Razavi, M.; Jamilian, M.; Karamali, M.; Bahmani, F.; Aghadavod, E.; Asemi, Z. The effects of vitamin D-K-calcium cosupplementation on endocrine, inflammation, and oxidative stress biomarkers in vitamin D-deficient women with polycystic ovary syndrome: A randomized, double-blind, placebo-controlled trial. Horm. Metab. Res. 2016, 48, 446-451. [CrossRef]

39. Jamilian, M.; Foroozanfard, F.; Rahmani, E.; Talebi, M.; Bahmani, F.; Asemi, Z. Effect of two different doses of vitamin D supplementation on metabolic profiles of insulin-resistant patients with polycystic ovary syndrome. Nutrients 2017, 9, 1280. [CrossRef] [PubMed]

40. Nasri, K.; Akrami, S.; Rahimi, M.; Taghizadeh, M.; Behfar, M.; Mazandaranian, M.R.; Kheiry, A.; Memarzadeh, M.R.; Asemi, Z. The effects of vitamin $\mathrm{D}$ and evening primrose oil co-supplementation on lipid profiles and biomarkers of oxidative stress in vitamin D-deficient women with polycystic ovary syndrome: A randomized, double-blind, placebo-controlled trial. Endocr. Res. 2018, 43, 1-10. [CrossRef]

41. Jamilian, M.; Samimi, M.; Mirhosseini, N.; Afshar Ebrahimi, F.; Aghadavod, E.; Talaee, R.; Jafarnejad, S.; Hashemi Dizaji, S.; Asemi, Z. The influences of vitamin D and omega-3 co-supplementation on clinical, metabolic and genetic parameters in women with polycystic ovary syndrome. J. Affect. Disord. 2018, 238, 32-38. [CrossRef]

42. Jamilian, M.; Amirani, E.; Asemi, Z. The effects of vitamin D and probiotic co-supplementation on glucose homeostasis, inflammation, oxidative stress and pregnancy outcomes in gestational diabetes: A randomized, double-blind, placebo-controlled trial. Clin. Nutr. 2019, 38, 2098-2105. [CrossRef] [PubMed]

43. Kyei, G.; Sobhani, A.; Nekonam, S.; Shabani, M.; Ebrahimi, F.; Qasemi, M.; Salahi, E.; Fardin, A. Assessing the effect of MitoQ10 and Vitamin D3 on ovarian oxidative stress, steroidogenesis and histomorphology in DHEA induced PCOS mouse model. Heliyon 2020, 6, e04279. [CrossRef] [PubMed]

44. Lajtai, K.; Tarszabo, R.; Banyai, B.; Peterffy, B.; Gerszi, D.; Ruisanchez, E.; Sziva, R.E.; Korsos-Novak, A.; Benko, R.; Hadjadj, L.; et al. Effect of vitamin D status on vascular function of the aorta in a rat model of PCOS. Oxid. Med. Cell Longev. 2021, 2021, 8865979. [CrossRef]

45. Jamilian, M.; Foroozanfard, F.; Mirhosseini, N.; Kavossian, E.; Aghadavod, E.; Bahmani, F.; Ostadmohammadi, V.; Kia, M.; Eftekhar, T.; Ayati, E.; et al. Effects of melatonin supplementation on hormonal, inflammatory, genetic, and oxidative stress parameters in women with polycystic ovary syndrome. Front. Endocrinol. 2019, 10, 273. [CrossRef] [PubMed]

46. Heshmati, J.; Golab, F.; Morvaridzadeh, M.; Potter, E.; Akbari-Fakhrabadi, M.; Farsi, F.; Tanbakooei, S.; Shidfar, F. The effects of curcumin supplementation on oxidative stress, Sirtuin-1 and peroxisome proliferator activated receptor $\gamma$ coactivator $1 \alpha$ gene expression in polycystic ovarian syndrome (PCOS) patients: A randomized placebo-controlled clinical trial. Diabetes Metab. Syndr. 2020, 14, 77-82. [CrossRef] [PubMed]

47. Ahmadi, S.; Jamilian, M.; Karamali, M.; Tajabadi-Ebrahimi, M.; Jafari, P.; Taghizadeh, M.; Memarzadeh, M.R.; Asemi, Z. Probiotic supplementation and the effects on weight loss, glycaemia and lipid profiles in women with polycystic ovary syndrome: A randomized, double-blind, placebo-controlled trial. Hum. Fertil. 2017, 20, 254-261. [CrossRef] [PubMed]

48. Lagowska, K.; Bajerska, J.; Jamka, M. The role of vitamin D oral supplementation in insulin resistance in women with polycystic ovary syndrome: A systematic review and meta-analysis of randomized controlled trials. Nutrients 2018, 10, 1637. [CrossRef]

49. Akbari, M.; Ostadmohammadi, V.; Lankarani, K.B.; Tabrizi, R.; Kolahdooz, F.; Heydari, S.T.; Kavari, S.H.; Mirhosseini, N.; Mafi, A.; Dastorani, M.; et al. The effects of vitamin D supplementation on biomarkers of inflammation and oxidative stress among women with polycystic ovary syndrome: A systematic review and meta-analysis of randomized controlled trials. Horm. Metab. Res. 2018, 50, 271-279. [CrossRef]

50. Jafari-Sfidvajani, S.; Ahangari, R.; Hozoori, M.; Mozaffari-Khosravi, H.; Fallahzadeh, H.; Nadjarzadeh, A. The effect of vitamin D supplementation in combination with low-calorie diet on anthropometric indices and androgen hormones in women with polycystic ovary syndrome: A double-blind, randomized, placebo-controlled trial. J. Endocrinol. Invest 2018, 41, 597-607. [CrossRef]

51. Krul-Poel, Y.H.; Snackey, C.; Louwers, Y.; Lips, P.; Lambalk, C.B.; Laven, J.S.; Simsek, S. The role of vitamin D in metabolic disturbances in polycystic ovary syndrome: A systematic review. Eur. J. Endocrinol. 2013, 169, 853-865. [CrossRef]

52. Yildizhan, R.; Kurdoglu, M.; Adali, E.; Kolusari, A.; Yildizhan, B.; Sahin, H.G.; Kamaci, M. Serum 25-hydroxyvitamin D concentrations in obese and non-obese women with polycystic ovary syndrome. Arch. Gynecol. Obstet. 2009, 280, 559-563. [CrossRef]

53. Joham, A.E.; Teede, H.J.; Cassar, S.; Stepto, N.K.; Strauss, B.J.; Harrison, C.L.; Boyle, J.; de Courten, B. Vitamin D in polycystic ovary syndrome: Relationship to obesity and insulin resistance. Mol. Nutr. Food Res. 2016, 60, 110-118. [CrossRef]

54. Zhao, J.F.; Li, B.X.; Zhang, Q. Vitamin D improves levels of hormonal, oxidative stress and inflammatory parameters in polycystic ovary syndrome: A meta-analysis study. Ann. Palliat. Med. 2021, 10, 169-183. [CrossRef]

55. Xue, Y.; Xu, P.; Xue, K.; Duan, X.; Cao, J.; Luan, T.; Li, Q.; Gu, L. Effect of vitamin D on biochemical parameters in polycystic ovary syndrome women: A meta-analysis. Arch. Gynecol. Obstet. 2017, 295, 487-496. [CrossRef]

56. Ross, J.A.; Kasum, C.M. Dietary flavonoids: Bioavailability, metabolic effects, and safety. Annu. Rev. Nutr. 2002, 22, 19-34. [CrossRef] [PubMed] 
57. Romualdi, D.; Costantini, B.; Campagna, G.; Lanzone, A.; Guido, M. Is there a role for soy isoflavones in the therapeutic approach to polycystic ovary syndrome? Results from a pilot study. Fertil. Steril. 2008, 90, 1826-1833. [CrossRef] [PubMed]

58. Dubey, P.; Thakur, V.; Chattopadhyay, M. Role of minerals and trace elements in diabetes and insulin resistance. Nutrients 2020, 12, 1864. [CrossRef] [PubMed]

59. Mirone, M.; Giannetta, E.; Isidori, A.M. Selenium and reproductive function. A systematic review. J. Endocrinol. Investig. 2013, 36, 28-36.

60. Hajizadeh-Sharafabad, F.; Moludi, J.; Tutunchi, H.; Taheri, E.; Izadi, A.; Maleki, V. Selenium and polycystic ovary syndrome: Current knowledge and future directions: A systematic review. Horm. Metab. Res. 2019, 51, 279-287. [CrossRef] [PubMed]

61. Shabani, A.; Noshadian, M.; Jamilian, M.; Chamani, M.; Mohammadi, S.; Asemi, Z. The effects of a novel combination of selenium and probiotic on weight loss, glycemic control and markers of cardio-metabolic risk in women with polycystic ovary syndrome. J. Funct. Foods 2018, 46, 329-334. [CrossRef]

62. Roberfroid, M.B. Prebiotics and probiotics: Are they functional foods? Am. J. Clin. Nutr. 2000, 71, 1682S-1687S. [CrossRef]

63. Fuller, R. Probiotics in human medicine. Gut 1991, 32, 439-442. [CrossRef]

64. Allen, S.J.; Jordan, S.; Storey, M.; Thornton, C.A.; Gravenor, M.; Garaiova, I.; Plummer, S.F.; Wang, D.; Morgan, G. Dietary supplementation with lactobacilli and bifidobacteria is well tolerated and not associated with adverse events during late pregnancy and early infancy. J. Nutr. 2010, 140, 483-488. [CrossRef]

65. Ejtahed, H.S.; Mohtadi-Nia, J.; Homayouni-Rad, A.; Niafar, M.; Asghari-Jafarabadi, M.; Mofid, V. Probiotic yogurt improves antioxidant status in type 2 diabetic patients. Nutrition 2012, 28, 539-543. [CrossRef]

66. Yadav, H.; Jain, S.; Sinha, P.R. Antidiabetic effect of probiotic dahi containing Lactobacillus acidophilus and Lactobacillus casei in high fructose fed rats. Nutrution 2007, 23, 62-68. [CrossRef] [PubMed]

67. Shoaei, T.; Heidari-Beni, M.; Tehrani, H.G.; Feizi, A.; Esmaillzadeh, A.; Askari, G. Effects of probiotic supplementation on pancreatic beta-cell function and C-reactive protein in women with polycystic ovary syndrome: A randomized double-blind placebo-controlled clinical trial. Int. J. Prev. Med. 2015, 6, 27. [CrossRef] [PubMed]

68. Tremellen, K.; Pearce, K. Dysbiosis of Gut Microbiota (DOGMA) - A novel theory for the development of Polycystic Ovarian Syndrome. Med. Hypotheses 2012, 79, 104-112. [CrossRef] [PubMed]

69. Guo, Y.; Qi, Y.; Yang, X.; Zhao, L.; Wen, S.; Liu, Y.; Tang, L. Association between polycystic ovary syndrome and gut microbiota. PLOS ONE 2016, 11, e0153196. [CrossRef]

70. Cicek, N.; Eryilmaz, O.G.; Sarikaya, E.; Gulerman, C.; Genc, Y. Vitamin E effect on controlled ovarian stimulation of unexplained infertile women. J. Assist. Reprod. Genet. 2012, 29, 325-328. [CrossRef]

71. Duleba, A.J.; Dokras, A. Is PCOS an inflammatory process? Fertil. Steril. 2012, 97, 7-12. [CrossRef]

72. Montanino Oliva, M.; Buonomo, G.; Calcagno, M.; Unfer, V. Effects of myo-inositol plus alpha-lactalbumin in myo-inositolresistant PCOS women. J. Ovarian Res. 2018, 11, 38. [CrossRef] [PubMed]

73. Ruan, X.; Dai, Y. Study on chronic low-grade inflammation and influential factors of polycystic ovary syndrome. Med. Princ. Pract. 2009, 18, 118-122. [CrossRef] [PubMed]

74. Kelly, C.C.; Lyall, H.; Petrie, J.R.; Gould, G.W.; Connell, J.M.; Sattar, N. Low grade chronic inflammation in women with polycystic ovarian syndrome. J. Clin. Endocrinol. Metab. 2001, 86, 2453-2455. [CrossRef] [PubMed]

75. Glintborg, D.; Andersen, M.; Richelsen, B.; Bruun, J.M. Plasma monocyte chemoattractant protein-1 (MCP-1) and macrophage inflammatory protein-1alpha are increased in patients with polycystic ovary syndrome (PCOS) and associated with adiposity, but unaffected by pioglitazone treatment. Clin. Endocrinol. 2009, 71, 652-658. [CrossRef] [PubMed]

76. Escobar-Morreale, H.F.; Botella-Carretero, J.I.; Villuendas, G.; Sancho, J.; San Millán, J.L. Serum interleukin-18 concentrations are increased in the polycystic ovary syndrome: Relationship to insulin resistance and to obesity. J. Clin. Endocrinol. Metab. 2004, 89, 806-811. [CrossRef]

77. Herlihy, A.C.; Kelly, R.E.; Hogan, J.L.; O'Connor, N.; Farah, N.; Turner, M.J. Polycystic ovary syndrome and the peripheral blood white cell count. J. Obstet. Gynaecol. 2011, 31, 242-244. [CrossRef]

78. De Jager, S.C.; Kraaijeveld, A.O.; Grauss, R.W.; de Jager, W.; Liem, S.S.; van der Hoeven, B.L.; Prakken, B.J.; Putter, H.; van Berkel, T.J.; Atsma, D.E.; et al. CCL3 (MIP-1 alpha) levels are elevated during acute coronary syndromes and show strong prognostic power for future ischemic events. J. Mol. Cell. Cardiol. 2008, 45, 446-452. [CrossRef]

79. Orio, F., Jr.; Palomba, S.; Cascella, T.; De Simone, B.; Di Biase, S.; Russo, T.; Labella, D.; Zullo, F.; Lombardi, G.; Colao, A. Early impairment of endothelial structure and function in young normal-weight women with polycystic ovary syndrome. J. Clin. Endocrinol. Metab. 2004, 89, 4588-4593. [CrossRef]

80. Tarkun, I.; Arslan, B.C.; Cantürk, Z.; Türemen, E.; Sahin, T.; Duman, C. Endothelial dysfunction in young women with polycystic ovary syndrome: Relationship with insulin resistance and low-grade chronic inflammation. J. Clin. Endocrinol. Metab. 2004, 89, 5592-5596. [CrossRef]

81. Zadeh Modarres, S.; Heidar, Z.; Foroozanfard, F.; Rahmati, Z.; Aghadavod, E.; Asemi, Z. The effects of selenium supplementation on gene expression related to insulin and lipid in infertile polycystic ovary syndrome women candidate for in vitro fertilization: A randomized, double-blind, placebo-controlled trial. Biol. Trace Elem. Res. 2018, 183, 218-225. [CrossRef] [PubMed]

82. Shahnazi, V.; Zaree, M.; Nouri, M.; Mehrzad-Sadaghiani, M.; Fayezi, S.; Darabi, M.; Khani, S.; Darabi, M. Influence of $\omega-3$ fatty acid eicosapentaenoic acid on IGF-1 and COX-2 gene expression in granulosa cells of PCOS women. Iran. J. Reprod. Med. 2015, 13, 71-78. [PubMed] 